\title{
Internal corporate governance and personal trust
}

\begin{abstract}
There are various indications that corporations and their leaders are currently not perceived as trustworthy. This decline in trust is one of the factors that has contributed to the rise of interest in corporate governance. There is an explicit expectation that an adherence to the principles and practice of good corporate governance will bolster the trust of stakeholders in business. It is exactly this expectation that provides the focus for this article. The expectation that good corporate governance will result in higher levels of trust will be critically examined. This will be done by first making some crucial distinctions regarding corporate governance in order to clarify what kind of corporate governance is at stake in the examination that is to follow. Also, with regard to the concept of 'trust', a number of important distinctions will be made to clarify what is meant by trust within the context of this paper. Against the backdrop of these distinctions regarding corporate governance and trust, the question will then be refined as to whether, specifically, internal corporate governance can bolster the perceptions of trustworthiness that stakeholders have of business. Principles and practices of internal corporate governance will then be critically examined to determine their potential for enhancing stakeholders' perceptions of the trustworthiness of corporations and their leaders.
\end{abstract}

Key words: corporate governance, trust, integrity, transparency, reputation, benevolence, corporate social responsibility

\section{Introduction}

That trust in business corporations is on the decline is beyond dispute. It was made very visible in the 1999 'Battle of Seattle' where disgruntled opponents of global capitalism tried to disrupt the World Trade Organisation (WTO) meeting. Since then several surveys have added further testimony to the reality of this phenomenon of ailing trust in business. A Gallup International poll in November 2002 revealed that the levels of trust in business corporations are very low. Since then a global opinion poll, conducted on behalf of the World Economic Forum in 20 countries, has found that the trust in business leaders is even lower than trust in the institutions they are leading (WEF, 2003). Only 33\% of people surveyed indicated that they had either 'a lot' or 'some trust' in business leaders. Business leaders also

Dr G.J. (Deon) Rossouw is Professor and Head of the Philosophy Department and Director of the Centre for Business and Professional Ethics at the University of Pretoria. He was the Founding President of the Business Ethics Network of Africa (BEN-Africa) and a former President of the International Society of Business, Economics, and Ethics (ISBEE). He served on the Sustainability Committee of the Third King Report of Corporate Governance for South Africa. enjoyed considerably less trust than leaders of NGOs, the UN and spiritual leaders.

These low levels of trust are clearly reflected in the 2003 Zogby Poll of college seniors in which 56\% of respondents agreed with the proposition that: 'the only real difference between executives at Enron and those of other big companies, is that those at Enron got caught' (Goodpaster, 2004:1). Business leaders are obviously scorched by these findings and some do not hesitate to acknowledge that rebuilding trust in corporations and their leaders is one of their major challenges. Ewald Kist, CEO of the ING Group, said: 'Restoring trust is the principal challenge that leaders of big companies have to face' (Kist, 2002:1). Tongue in cheek, Ann Crotty writes in Directorship: 'There was time when filling in "company director", to the oft-asked question about one's occupation was guaranteed to evoke sycophancy from all quarters except the few sad die-hard old socialists. Now it is much more likely to be greeted by sideways glances of embarrassment and sympathy. And no doubt if you're looking closely enough you will see mothers whispering dire warnings to their children and tightly clutching the whatever few pence they have on their person. These days you may as well be a litigation lawyer or even a journalist for all the respect you're likely to get as a director' (2004:19).

That these low levels of trust are a matter of great concern for corporations and their leaders is further illustrated in the fact that the theme of the 2003 World Economic Forum meeting in Davos was 'Building Trust during a time of Global Uncertainty and Mistrust'. There is however an expectation that adherence to the principles and practices of good corporate governance might turn the current tide of low trust in corporations and their leaders (Payne, 2004:6). In fact, the current emphasis on corporate governance is often seen as a direct response by business to counter the devastating effects that a series of well-publicised business scandals have had on the image of business in general. This point is well illustrated in the fact that the report on corporate governance reforms required in MCI (the former WorldCom) is titled: 'Restoring Trust' (Breeden, 2003). The objective of this paper is to determine whether this belief in the potential of corporate governance to cure the ailing trust in business is justified.

Both corporate governance and trust are concepts with broad meanings. Consequently it is important to specify the scope of these concepts in order to focus the discussion. I will, therefore, start by defining corporate governance and then draw a distinction between internal and external corporate governance, 
as the rest of the paper will focus only on internal corporate governance. Thereafter, the concept of trust will be defined and two important distinctions, viz. between personal and procedural trust as well as between trust and trustworthiness, will be made, as the rest of the paper will focus only on the concepts of personal trust and trustworthiness. Against the backdrop of these distinctions, the question will then be posed whether internal corporate governance reforms can bolster stakeholders' perceptions of the trustworthiness of corporations and their leaders.

\section{Corporate governance}

Corporate governance can be defined either rather narrowly or fairly broadly. Narrow definitions of corporate governance are premised upon agency theory that states that managers as the agents of owners (or shareholders) are obligated to act in the best financial interest of the owners of the corporation (cf. Monks \& Minow, 1995:113). An example of a narrow definition of corporate governance is Shleifer and Vishny's definition of corporate governance as 'the ways in which suppliers of finance to corporations assure themselves of getting a return on their investment' (1997:737). Such narrow conceptions of corporate governance will be referred to as the 'exclusive corporate governance model' in the remainder of the paper.

Broader definitions of corporate governance are premised upon stakeholder theory and conceive the corporation as a social institution (cf. Evan \& Friedman, 1993:82). Corporate governance is, accordingly, defined as the system that ensures that the board and management of corporations strike a balance between the interests of their various stakeholders. Collier and Roberts state that when the corporation is conceived as a social institution, corporate governance is about 'aligning and balancing a wide variety of potentially competitive interests within the corporation' (2001:67). A similarly broad notion of corporate governance is evident in the second King Report on Corporate Governance for South Africa 2002 when it states in the introduction to the report that the key challenge is 'to seek an appropriate balance between enterprise (performance) and constraints (conformance), so taking into account the expectation of shareowners for reasonable capital growth and the responsibility concerning the interests of other stakeholders of the company' (IoD, 2002:6). Such broad conceptions of corporate governance will in the remainder of the paper be referred to as the 'inclusive corporate governance model'.

Besides the distinction between narrow and broad definitions of corporate governance (or exclusive and inclusive models of corporate governance), a distinction can also be made with regard to whether the locus of control for corporate governance is internal or external to corporations (cf. Rossouw, Van der Watt \& Malan, 2002). Conceptions of corporate governance that emphasise the internal dimension of corporate governance locate the responsibility for corporate governance in the board and executive management of a corporation. On this level governance refers to the way in which a company directs and controls its own affairs. The most widely used definition of corporate governance on this level is the one that was introduced by the Cadbury Report on Corporate Governance in the UK which defined it as: 'the system by which a company is directed and controlled' (Smerdon, 1998:1). The responsibility for corporate governance thus lies with the board of directors and executive management of a corporation and consists of two main functions: the direction and control of the company. The board of directors and executive management is firstly responsible for determining the strategic direction and hence the ultimate performance of the company. (Reinecke, 1996:11). Secondly, they are responsible for the control of the company. This is referred to as their conformance responsibility. It entails supervising management to ensure that they execute strategic decisions effectively as well as accounting to stakeholders for the way in which the company is being run.

These two internal corporate governance responsibilities are demonstrated in the figure below:

\begin{tabular}{|c|c|c|}
\hline $\begin{array}{l}\text { Supervising } \\
\text { management }\end{array}$ & & Strategic planning \\
\hline $\begin{array}{l}\text { CONTROL } \\
\text { Conformance }\end{array}$ & $\begin{array}{l}\text { Board of } \\
\text { directors }\end{array}$ & $\begin{array}{l}\text { DIRECT } \\
\text { Performance }\end{array}$ \\
\hline Accountability & & Executive action \\
\hline
\end{tabular}

Figure 1: Governance responsibilities of board of directors

Source: Adapted from Garratt (2003)

The locus of control for corporate governance can also be located outside or above corporations on the regulatory level. On this level corporate governance refers to the regulatory environment within which corporations function. It consists of the control over companies that is exerted from the outside. For example, the state, the judiciary and stock exchanges exercise such external control over companies in general and over securities transactions in particular (Coffee, 1998:69; Romano, 1998:144). The state may also opt for delegating some of its control over companies to regulatory bodies. All of these arrangements combine to form the landscape of external corporate governance. The purpose of such control over the operations of companies is not only to lay down ground rules for key role players in order to provide protection to shareholders and/or stakeholders in corporate action but also to prevent the market as such from failing due to malpractices (Romano, 1998:148). 
Other than the case with narrow and broad conceptions of corporate governance, internal and external conceptions of corporate governance do not exclude one another, but should ideally co-exist and complement one another. Wieland's definition of corporate governance 'as leadership, management and control of a firm by formal and informal, public and private rules' (2005:76) is a clear attempt to integrate both the external and internal dimensions of corporate governance into one comprehensive definition.

The table below illustrates that corporate governance can be either narrowly or broadly conceived and that the locus of control can be either internally and/or externally located.

TABLE 1: LEVELS AND SCOPE OF CORPORATE GOVERNANCE

\begin{tabular}{lll}
\hline & $\begin{array}{l}\text { Internal } \\
\text { Enterprise level }\end{array}$ & $\begin{array}{l}\text { External } \\
\text { Regulatory level }\end{array}$ \\
\hline Narrow & \\
Agency theory & \\
\hline Broad & \\
Stakeholder theory & \\
\hline
\end{tabular}

The distinction between internal and external corporate governance is especially important in refining the question on whether corporate governance can enhance trust in corporations and their leaders. Before I attend to the said distinction I will first clarify some aspects of the concept 'trust' in the next section.

\section{Trust}

The theoretical discourse on trust has made significant strides in recent years. No longer is trust treated as an amorphous concept that is described by Flores and Solomon (1998:206) with terminology such as 'the basic stuff or ingredient of social interaction' (with reference to Benjamin Barber), 'a resource' (with reference to Francis Fukuyama) or as 'medium', 'ground', or 'atmosphere'. Not only have more adequate definitions of trust been formulated, but a number of important distinctions signifying different kinds of trust have emerged. Below I will discuss some of these distinctions that have a direct bearing on the scope of this paper. I will attend to the definition of trust, distinguish between different kinds of trust and discuss the related concept of trustworthiness.

\section{Definition of trust}

Central to the recent generation of definitions of trust are the concepts 'vulnerability' and 'reliance' (Soule, 1998:261). Trust refers to the propensity of persons to take the risk of making themselves vulnerable by relying on others for the protection or enhancement of their interests. The seminal work done by Mayer, Davis and Schoorman has made an important contribution to the new generation of trust definitions. They defined trust as: 'the willingness of a party to be vulnerable to the actions of another party based on the expectation that the other will perform a particular action important to the trustor, irrespective of the ability to monitor or control that other party' (1995:712).

\section{Kinds of trust}

The quality of trust relations can vary both in terms of time and intensity. Some trust relations are merely temporary, whilst others are more enduring. Equally in terms of intensity, some trust relations might be superficial whilst others are profound. Furthermore, trust might reside in persons or in institutional arrangements like procedures and contracts. These variations in trust have led to a number of different kinds of trust being distinguished.

For the purpose of this paper, I shall make a distinction between personal (or socially embedded) trust and procedural (or impersonal) trust. The former signifies trust that stems from the interaction between persons, whilst the latter refers to trust that is cultivated through formal bureaucratic arrangements or procedures. An example of personal trust is when an individual is willing to entrust her assets to another person based on the knowledge that she has of the other person. Procedural trust, however, is displayed when someone is willing to entrust his assets to an institution based on knowledge that he has of the procedures and policies that the institution abides by.

Both these two kinds of trust apply to business organisations. Some interactions between a business and its stakeholders depend on personal trust, whilst others are premised on procedural trust (cf. Granovetter, 1985:491; Shapiro, 1987:624; Bigley \& Pearce, 1998:405). Each of these two kinds of trust has a unique set of requirements. For procedural trust to be enhanced, it is important that procedures are such that conflicts of interest are avoided, responsibilities of principals and agents are clarified, decision-making rules are established, sanctions for non-compliance to the procedure are stipulated, etc. (cf. Bigley \& Pearce, 1998:632). In the case of personal trust, a different set of requirements determines whether personal trust will be enhanced or diminished. Personal trust does not only depend on the propensity of the person who is trusting, but also on the characteristics of the person or institution who is trusted. The role played by the characteristics of the person (or institution) that is trusted in personal trust relations, brings the concept of trustworthiness into play.

\section{Trustworthiness}

Trust, in the sense of a willingness (as defined above) that emanates from a trustor (the person who trusts) needs to be distinguished from the related concept of 
trustworthiness (Bews \& Rossouw, 2002:150). Where trust is a disposition (propensity or attitude) displayed by a trustor, trustworthiness is a characteristic of a trustee (the person who is trusted). It is an evaluation of the quality of a person as a trustee. Trustworthiness thus refers to an assessment of whether a trustee possesses characteristics or qualities that potentially can influence the willingness of a trustor to make himself vulnerable by relying on the trustee. Trustworthiness as a quality can be ascribed to both persons and institutions (Brenkert, 1998:300).

Studies on trustworthiness have revealed that a person's trustworthiness depends upon a number of characteristics. In the literature on trust we find that a variety of terms are used to refer to the factors that enhance trustworthiness, such as 'antecedents' (Mayer et al., 1995; Dibben, 2000); 'dimensions' (Mishra, 1996; Robbins, 1997) and the 'characteristics' (Engelbrecht \& Cloete, 2000) of trustworthiness. Following Bews (2000), I will refer to those factors on which an evaluation of the trustworthiness of a person or institution is based as facilitator of trustworthiness.

In the literature on trust an array of labels are attached to these facilitators of trustworthiness. Mayer et al. (1995) mention ability, benevolence and integrity, Mishra (1996) refers to competency, openness, concern and reliability, while Robbins (1997) includes integrity, competency, loyalty and openness. In his study of the facilitators of trustworthiness, Bews (2000) argues that although different theorists use different terms to describe facilitators of trustworthiness, an overlapping consensus amongst the terms can be discerned. He found that theorists agree that trustworthiness correlates significantly with characteristics such as openness, competency, integrity, and benevolence. Also Becerra and Huemer came to a similar conclusion (2002:80). People who display these characteristics are judged to be more trustworthy than those who lack these qualities. If one assumes that perceptions of these qualities can be influenced by how trustees behave, then it suggests that trustworthiness is a quality that can be developed and enhanced (Bews \& Rossouw, 2002; Verstegen Ryan \& Buchholtz, 2001:183). I will now turn to the relationship between internal corporate governance and the perceived trustworthiness of corporations and their leaders.

\section{Corporate governance and trust}

Against the backdrop of the above distinctions between internal and external corporate governance, between personal and procedural trust, as well as between trust and trustworthiness, the remainder of this paper will focus on the relation between internal corporate governance and the trustworthiness of corporations and their leaders in personal trust relations. This is not to deny that there also might be a direct relation between corporate governance both on the internal and external levels and procedural trust, but that is a topic for another occasion. In this paper the pertinent question is: Can adherence to good internal corporate governance enhance the trustworthiness of corporations and their leaders in personal trust relations? This question will be explored by taking the four facilitators of personal trustworthiness as defined above by Bews, viz. openness, competence, integrity and benevolence ${ }^{1}$, and then determining whether good internal corporate governance can enhance these characteristics of corporations.

It is safe to assume that the characteristics that enhance the trustworthiness of persons will also enhance the trustworthiness of corporations. That is, if persons characterised by openness, competence, integrity and benevolence are more likely to be perceived as trustworthy, then it can be accepted that corporations displaying these same characteristic will likewise be perceived as more trustworthy compared to their counterparts who lack these characteristics. Furthermore if corporations are considered as moral agents as French (1993) and others consider them to be (cf. Kaptein \& Wempe, 2002:123-137), one can assume that as agents they also display the above characteristics, which are all intimately linked with moral behaviour. It is in fact not uncommon to associate corporations with these characteristics or their lack. Corporate openness (or transparency), corporate competency, corporate integrity and corporate benevolence indeed are terms that are widely used in the discourses on corporate ethics and corporate social responsibility. It will further be assumed that internal corporate governance reforms will not only have an impact on how the trustworthiness of corporations is perceived but also on how the trustworthiness of their most visible representatives, i.e. corporate leaders, will be perceived.

Each of the four facilitators of trustworthiness that have been identified above will now be discussed in order to determine whether internal corporate governance reforms can indeed enhance stakeholders ${ }^{1}$ perceptions of the trustworthiness of corporations and their leaders. These four facilitators of trustworthiness will be discussed in the following sequence: openness, competency, integrity and benevolence.

\section{Openness}

Openness refers to how freely persons or institutions make information available to people who are affected by that information (Mishra, 1996). Various researchers including Martins, Robbins and Hay found that openness correlates positively with trustworthiness (cf. Bews, 2000:26). The quality of 'openness' has a distinct moral undertone as the disclosure of information can assist those who are affected by the information to either advance or protect their interests. Failure to disclose such information effectively bars those affected by it from 
enhancing or protecting their interests. Consequently, a lack of openness on the side of a business and its leaders will be perceived as unfair or immoral by its stakeholders, which in turn will undermine stakeholders' perceptions of the trustworthiness of a business.

Openness is an attribute that can be modified. Both individuals and institutions can modify their levels of openness by sharing relevant information with affected parties. Companies can introduce strategies, systems and procedures that facilitate more openness in communication with stakeholders. In this regard internal corporate governance can play a role in enhancing the openness with which corporations deal with their stakeholders.

Most corporate governance models emphasise the need for regular and sufficient disclosure of information by corporations to their stakeholders. However, where corporate governance models differ, is with regard to what information should be disclosed and to whom it should be disclosed. These differences between various models of corporate governance coincide with the distinction between exclusive and inclusive models of governance that was introduced in the above discussion on corporate governance. In exclusive models, which are only shareholder focussed, the need for disclosure is emphasised, but only with regard to shareholders. Such disclosure to shareholders can enhance the perception of shareholders with regard to the openness of companies, and thus improve their perception of the trustworthiness of the companies they have invested in. The problem with exclusive models, however, is that they will not succeed in enhancing the perception of openness among the other stakeholders of the business. The charge of Collier and Roberts will inevitably stick that the only ethical imperative at work here is a Friedmanesque dictum to pursue profit maximization' (2001:8).

Inclusive models of corporate governance that emphasise that corporations should not only be accountable to their shareholders, but also have moral obligations to their other stakeholders, stand a better chance of improving the perception of a corporation's openness among all its stakeholders. In order to enhance the perception of openness, it is imperative that the corporation identifies its stakeholders and regularly engages with them. Through stakeholder engagement the company can determine what information is material to its stakeholders, and disclose the information required by them to them through a process of ongoing stakeholder dialogue. The information required by the non-shareholding stakeholders of a corporation is likely to be more than mere information on the economic performance of the corporation. They are likely to demand information on the social-ethical and environmental performance of the company. Companies that regularly disclose information on their triple bottom-line performance through processes of shareholder and stakeholder engagement are more likely to be perceived as open by their stakeholders. Should adherence to internal corporate governance standards of disclosure result in positive perceptions of the openness of a corporation, it can enhance stakeholders' perceptions of the trustworthiness of corporations and their leaders.

\section{Competency}

Competence is defined by Mayer et al. as the knowledge and skills needed by a person to influence the domain for which they are responsible (1995:717). In the case of internal corporate governance this competence refers specifically to the ability of a board and executive management to ensure that the enterprise is economically successful and sustainable. The emphasis that is placed in most models of governance on board compilation and on board and management effectiveness obviously bears the potential of improving board and executive management performance.

The proper compilation of a board with a sound mix of executive, non-executive and independent non-executive directors plus the emphasis on a wellbalanced mix of expertise around the boardroom table can enhance the performance of a corporation on both the single and triple bottom-line. The further emphasis on the duties of directors as well as the need for the regular review of board performance can ensure that that the effectiveness of board and executive management performance is improved (Garratt, 2003:119). Various commendable initiatives have recently been taken to improve the levels of skill and knowledge of directors. These include the introduction of the qualification of 'chartered director' as well as various other directors' training initiatives by amongst others the Commonwealth Association of Corporate Governance (CACG) and the World Bank.

Despite the hopes raised by these competenceenhancing initiatives there is a dark underbelly of corporate governance that might undo the potential of internal corporate governance reforms to enhance perceptions of competency. This dark side of internal corporate governance is the currently widely lamented over-emphasis on conformance at the cost of performance of companies. There is concern that the demand for conformance to various accountability standards and disclosure requirement drains the energy and focus of the board and executive management away from company performance. This situation is further aggravated by the ever more stringent demands imposed by financial regulators on boards and executive management and also by the personal liability that executive and non-executive directors potentially face in the case of corporate scandals and failures. The Sarbanes-Oxley Act in the US context is often hailed as 
the pinnacle of this development. A publication by IFAC (International Federation of Accountants) with the title, Enterprise governance: Getting the balance right, emphasises that the balance between conformance and performance has been skewed by recent corporate governance reforms. The reports mentions that in a survey of senior managers from around the world it was reported that 'top management is spending more time on governance now than it did in the previous year and expects that more time will be devoted to the issue in future' (2004:9). (Governance within the context of the IFAC report refers to conformance responsibility of managers.)

When corporate governance reform has the effect of over-emphasising conformance, it not only can distract the board and executive management from their responsibility of enhancing company performance, but might also make them risk averse. As corporate success is often intimately linked to risk taking the current over-emphasis on conformance at the expense of corporate performance might create the perception that boards and executive management teams are not competent to govern the performance of corporations effectively. Should this result in lower economic performance, not only shareholders, but all other stakeholders who stand to benefit from the economic performance of the company, might question the competency of a corporation and its leaders. Consequently, corporate governance reform can ironically, despite its noblest intentions of enhancing board competence, result in undermining the performance of companies.

The overemphasis of conformance at the cost of performance should notbeblamed on theidea of corporate governance, but rather on a skewed development in the way in which governance is implemented by companies and enforced by regulators. The approach by IFAC (International Federation of Accountants) to introduce a new concept, called 'Enterprise Governance', to emphasise corporate performance, and to reserve the term corporate governance for conformance, is unfortunate (IFAC, 2004). What is required is not more new terminology, but rather an act of restoration that will strike a sound balance between performance and conformance. There is a growing body of empirical evidence (e.g. the McKinsey $(2001 ; 2002)$ and Deutsche Bank surveys) that indicates that good corporate governance correlates with improved corporate performance and enhanced investor confidence.

Thus corporate governance does have the potential to increase stakeholder perceptions of competence, but obviously, in the light of the above discussion, also the potential to do the opposite. Perceptions of the trustworthiness of corporations on the competency score will only be enhanced by internal corporate governance if it results in companies and their leaders performing well on both the performance and conformance dimensions of internal corporate governance.

\section{Integrity}

Integrity is sometimes defined around the concepts 'consistency' and 'reliability' (Seiling, 1997:131). There is, however, also a moral element needed before integrity can be ascribed to a person or institution. A person, who is consistently ill-behaved to the extent that one can almost rely on this person to act in that fashion, does not fit the description of a person with integrity. The moral element implied in the concept of integrity is that of fairness. Fairness refers to the moral consideration of the interests of others. The literature on trust highlights these features of integrity, for instance, Barber (in Husted, 1998) emphasises 'moral obligations'. Mayer et al. (1995) list integrity as an antecedent of trust under which they include fairness, consistency and reliability, while Engelbrecht and Cloete (2000) confirmed Mayer et al.'s notion of integrity in their research.

We thus ascribe integrity to persons or institutions when they consistently act in a fair or ethical manner (Husted, 1998; Mishra, 1996). One consequently can rely on them, because you know that they are unlikely to deviate from their ethical values. This link between integrity and ethics is so intimate that the two concepts are often used as synonyms. The integrity of both corporate leaders and corporations is a recurring theme in internal corporate governance.

It is hard to find a corporate governance code that does not emphasise the importance of ethical values and adherence thereto by corporations and corporate leaders. The reputational benefits of sound ethical performance as well as the reputational danger of unethical behaviour are widely acknowledged. Often this is, however, where it remains. A commitment to ethics and a good reputation needs to be translated into strategies, plans, policies and systems, before it will become institutionalised as organisational integrity.

While most corporate governance codes deal in detail with how companies should go about governing their economic performance and how they should account, audit and disclose it, the same cannot be said of the governance of ethical performance. Although the words 'ethical', 'moral' and 'integrity' often feature in such documents, little effort is made to spell out what the governance of ethics entails. Also the Global Reporting Initiative (GRI) guidelines that are setting the global standard for triple bottom-line (sustainability) reporting provide scant guidance on how companies should report on their ethical performance. The closest the GRI guidelines get to reporting on organisational integrity, are the guidelines that it provides on what internal and external social issues companies should report on.

A number of notable exceptions do however exist. The second King Report on Corporate Governance for South Africa 2002 (IoD, 2002), for example, outlines what the process of governing ethical performance consists of. Also the Sarbanes-Oxley Act and the Federal Sentencing 
Guidelines in the USA indicate key elements of what the governance of ethical performance should consist of.

The proper governance of the ethical performance of corporations requires that a board should oversee the processes of assessing a company's ethics risk profile, codifying and institutionalising its ethical standards, reporting its ethical performance and having it audited and disclosed to relevant internal and external stakeholders (cf. Rossouw \& Van Vuuren, 2004:197). Only such a concerted effort will ensure that perceptions of the integrity of a company and its leaders are enhanced. Once more it is clear that if the integrity of corporations and their leaders is bolstered through adequate internal corporate governance reforms, perceptions of their trustworthiness will be enhanced as well.

\section{Benevolence}

Benevolence is demonstrated in actively doing what is good for others. In order to be perceived as trustworthy, a trustee should at the very least be perceived as not taking advantage of the vulnerability of a trustor. Although not taking advantage is a necessary condition for benevolence, it is not sufficient. The trustee should also take an active interest in the well-being of the trustor (Mayer et al., 1995). In this regard, Mishra said that trustworthiness is enhanced by the willingness of the trustee to '... also be concerned about my interests or the interests of the whole' (1996:267). Hosmer adds to this by pointing out that trustees 'clearly go beyond a negative promise not to harm the interest of the other party; they seem to provide a positive guarantee that the rights and interests of the other party will be included in the final outcome' (1995:392).

In the literature on trust, concepts such as 'loyalty', 'concern', 'goodwill', 'altruism' and 'benevolence' all feature as important facilitators of trustworthiness. Mayer et al. (1995) regard benevolence as an antecedent of trust finding support from Stickland and Solomon who also make reference to benevolence. Engelbrecht and Cloete (2000), who tested Mayer et al.'s model of trust, equally found empirical support to regard benevolence as a facilitator of trust (see also Bews \& Rossouw, 2002).

Both inclusive and exclusive models of corporate governance emphasise the need for taking active care of the interests of stakeholders - the difference between the two models once again being the scope of stakeholders for whom the board should care. In the case of exclusive models of corporate governance (premised upon agency theory), care is restricted to the interests of shareholders, and the interests of other stakeholders are considered only in as far as they might have an impact on the interests of shareholders. In the case of inclusive models (premised upon normative stakeholder theory), care is extended to all stakeholders of business. In the earlier discussion on these two models, it was pointed out that an exclusive model stands the chance of improving only shareholders' perceptions of the trustworthiness of the corporation and its leaders, but runs the risk of alienating other stakeholders. The same argument applies here. There is no dispute over the fact that a board of directors and the executive management should act benevolently towards the shareholders of the company. But should the board of directors and the executive management be concerned only about protecting or enhancing the interests of shareholders, they most likely will not be perceived as trustworthy by the non-shareholding stakeholders of the company. If the board and executive management is thus concerned about improving the trustworthiness of the company amongst all its stakeholders, all of them need to be treated benevolently.

The emphasis on benevolence in internal corporate governance is reflected in terms such as 'corporate social responsibility', 'corporate citizenship' and 'licence to operate' that often permeate the corporate governance discourse. Within the context of triple bottom-line reporting it falls under the social performance of a company, but can also extend to its environmental performance. As part of a company's social performance a distinction can be made between internal social performance and external social performance (cf. Rossouw \& van Vuuren, 2004:199-200). The internal social performance of a company relates to the benevolence of a company towards its employees. The board needs to ensure that the safety and health of employees are being taken care of and that opportunities for their development are created.

External social performance relates to the way in which companies interact with external stakeholders such as customers, suppliers and the communities within which they operate. To enhance its trustworthiness through benevolence towards these external stakeholders, companies will have to move beyond a reactionary mode of benevolence where they merely approve or reject requests for funding by individuals or non-profit organisations. A more pro-active approach is required to bolster perceptions of the benevolence of companies. This involves actively engaging with stakeholders to determine their interests and needs. Such strategies need not only be well attuned with the company's vision, mission and resources, but also have to be governed properly. This entails the entire process from designing strategies to the implementation and monitoring thereof up to the point of reporting and disclosing the internal and external social performance of the company (Ilett, 2004:10).

Companies that engage in the above pro-active manner with all their stakeholders can expect to improve the perception that their stakeholders have of their benevolence. In reporting and disclosing their social performance they can further hope to enhance their reputation, which will also contribute towards their trustworthiness. 


\section{Conclusion}

In the introduction to this paper the question was raised whether the belief in the potential of corporate governance to cure the ailing trust in business is justified. In the light of the above discussion this question can be answered with a qualified yes. The above discussion has demonstrated that internal corporate governance has the potential to enhance perceptions of openness, competence, integrity and benevolence. As these four qualities are the facilitators of trustworthiness in personal trust relations, it can be concluded that internal corporate governance can enhance perceptions of the trustworthiness of corporations and their leaders. However, this affirmative answer is marked by at least three important qualifications.

Firstly, the answer does not refer to all forms of corporate governance, neither to all forms of trust, but only to internal corporate governance and its potential impact on perceptions of the trustworthiness of corporations and their leaders within the context of personal trust relations. The relation between procedural trust and corporate governance on both the enterprise and regulatory level has been excluded from the investigation and therefore needs to be investigated as well before comprehensive judgement can be passed on the relationship between corporate governance and trust in business.

Secondly, not all models of internal corporate governance have the potential of bolstering perceptions of trustworthiness. If internal corporate governance is not applied in a manner that enhances openness, competence, integrity and benevolence towards both its shareholders and primary stakeholders, it can become counter-productive and result in the alienation of certain stakeholder groups. Especially the exclusive model of internal corporate governance runs the risk of damaging perceptions of trustworthiness of corporations and their leaders amongst non-shareholding stakeholders.

Thirdly, it needs to be stressed that the focus has been merely on perceptions of trustworthiness. Perceptions can be manipulated by shrewd corporate leaders and therefore perceptions of trustworthiness do not necessarily translate into more reliable or responsible behaviour by corporations and their leaders. It is, however, to be expected that such manipulated perceptions of trustworthiness will have a relatively short shelf life, which can harm the trustworthiness of corporations and their leaders when they are unmasked.

\section{Note:}

${ }^{1}$ Bews also makes reference to history of interactions and personality factors as facilitators of trustworthiness. These two facilitators will not be included in the discussion as it is my contention that the history of interaction is merely the cumulative experience of the four facilitators that will be discussed and therefore is not in need of further discussion - see my argument in this regard in Bews \& Rossouw, 2002. The facilitator, 'personality factors', is excluded as it does not apply to corporations. Although I agree with French (1993) that corporations can be regarded as moral agents, it does not mean that personalities can be ascribed to them as well - see my argument on this point in Rossouw \& Van Vuuren (2003).

\section{References}

Becerra, M. \& Huemer, L. 2002. Moral character and relationship effectiveness: An empirical investigation of trust within organizations. In Von Weltzien Hoivik (ed.) Moral leadership in action. Cheltenham, UK: Edward Elgar.

Bews, N.F. 2000. An investigation into the facilitators of the trustworthiness of managers. Doctoral dissertation. Johannesburg: Rand Afrikaans University.

Bews, N.F. \& Rossouw, G.J. 2002. A role for business ethics in facilitating trustworthiness. Journal of Business Ethics, 39: 377-390.

Bigley, G.A. \& Pearce, J.L. 1998. Straining for shared meaning in organization science: Problems of trust and distrust. The Academy of Management Review, 23(3): 405-421.

Breeden. R.C. 2003. Restoring trust. New York: Report to the United States District Court for the Southern District of New York.

Brenkert, G.G. 1998. Trust, morality and international business. Business Ethics Quarterly, 8(2): 293-317.

Coffee, J.C. 1998. Inventing a corporate monitor for transitional economies: The uncertain lessons from the Czech and Polish experiences. In K.J. Hopt et al. Comparative corporate governance: The state of the art and emerging research. New York: Oxford University Press. pp. 67-138.

Collier, J. \& Robberts, J. 2001. An ethic for corporate governance? Business Ethics Quarterly, 11(1): 67-71.

Crotty, A. 2004. Called to account. Directorship, March: 19.

Dibben, M.R. 2000. Exploring interpersonal trust in the entrepreneurial venture. London: MacMillan Press.

Engelbrecht, A.S. \& Cloete, B.E. 2000. An analysis of a supervisor-subordinate trust relationship. Journal of Industrial Psychology, 26(1): 29-38.

Evan, W. \& Freeman, R. 1993. A stakeholder theory of the modern corporation: Kantian capitalism. In $\mathrm{T}$. Beauchamp \& N. Bowie (eds.) Ethical theory and business (4th edition). New Jersey: Prentice Hall.

Flores, F. \& Solomon, R.C. 1998. Creating trust. Business Ethics Quarterly, 8(2): 205-232.

French, P. 1993. The corporation as moral person. In T.I. White (ed.) Business ethics: A philosophical reader. New York: MacMillan.

Garratt, B. 2003. Thin on top. London: Nicholas Brealey.

Goodpaster, K.E. 2004. Ethics or Excellence? Conscience as a check on the unbalanced pursuit of organizational goals. Ivey Business Journal, March/April: 1-8. 
Granovetter, M. 1985. Economic action and social structure: The problem of embeddedness. American Journal of Sociology, 91: 481-510.

Hosmer, L.T. Trust: The connecting link between organisational theory and philosophical ethics. Academy of Management Review, 20(2): 379-403.

Husted, B.W. 1998. The ethical limits of trust in business relations. Business Ethics Quarterly, 8(2): 233-248

IFAC. 2004. Enterprise governance: Getting the balance right. International Federation of Accountants. [Online]. Available: www.ifac.org. Accessed in February 2007.

Ilett, D. 2004. How socially responsible is your company? Directorship, March: 10-11.

IoD. 2002. King Report on Corporate Governance for South Africa 2002. Johannesburg: Institute of Directors.

Kaptein M. \& Wempe, J. 2002. The Balanced company: A theory of corporate integrity. Oxford: Oxford University Press.

Kist, E. 2002. Restoring and building trust in a turbulent world. Paper delivered at Yale University on 15 November 2002.

Mayer, R.C., Davis, J.H., \& Schoorman, F.D. 1995. An integrative model of organizational trust. Academy of Management Review, 20(3): 709-734.

McKinsey and Company. 2001. Investor opinion survey on corporate governance. London: McKinsey and Company.

McKinsey \& Company. 2002. Investor opinion survey on corporate governance. London: McKinsey and Company.

Mishra, A.K. 1996. Organizational responses to crisis: The centrality of trust. In R.M. Kramer \& T.R. Tyler (eds.) Trust in organizations: Frontiers of theory and research. Thousand Oaks, California: Sage.

Monks, R.A.G. \& Minow, N. 1995. Corporate governance. Oxford: Blackwell.

OECD. 2004. OECD principles of corporate governance. Paris: OECD Publications.

Payne, N. 2004. Board Effectiveness. Directorship, March: 6-7.

Reinecke, M.P.A. 1996. Effective corporate governance: A South African perspective. Masters dissertation. Johannesburg: Rand Afrikaans University.

Robbins, S.P. 1997. Essentials of organizational behaviour (5th edition). Upper Saddle River, NJ: Prentice-Hall.
Romano, R. 1998. Empowering investors: a market approach to securities regulation. In K.J. Hopt et al. Comparative corporate governance: the state of the art and emerging research. New York: Oxford University Press. pp. 143-217.

Rossouw, D., Van der Watt, A. \& Malan, D. 2002. Corporate Governance in South Africa. Journal of Business Ethics, 37: 289-302.

Rossouw, G.J. \& Van Vuuren, L.J. 2003. Modes of managing morality: A descriptive model of strategies for managing ethics. Journal of Business Ethics, 46: 389-402.

Seiling, J.G. 1997. The membership organization. Palo Alto (CA): Davies-Black.

Shapiro, 1987. The social control of impersonal trust. American Journal of Sociology, 93(3): 623-658.

Shleifer, A. \& Vishny, R.W. 1997. A survey of corporate governance. The Journal of Finance, LII(2): 737-783.

Smerden, R. 1998. A practical guide to corporate governance. London: Sweet \& Maxwell.

Soule, E. 1998. Trust and managerial responsibility. Business Ethics Quarterly, 8(2): 249-272.

Verstegen Ryan, L. \& Buchholtz, A.K. 2001. Trust, risk and shareholder decision making: an investor perspective on corporate governance. Business Ethics Quarterly, 11(1): 177-193.

WEF. 2003. Declining public trust foremost a leadership problem. World Economic Forum. [Online]. Available: www.weforum.org.

Wieland, J. 2005. Corporate governance, values management, and standards: a European perspective. Business and Society, 44(1): 74-93.
Address correspondence to:
Deon Rossouw
Department of Philosophy
University of Pretoria
Pretoria, South Africa, O001
e-mail: deon.rossouw@up.ac.za 
Reproduced with permission of the copyright owner. Further reproduction prohibited without permission. 